\title{
KESEDIAAN MEMBAYAR PETANI KOPI UNTUK PERBAIKAN LINGKUNGAN
}

\author{
Fembriarti Erry Prasmatiwi ${ }^{1}$, Irham ${ }^{2}$, Any Suryantini ${ }^{2}$, dan Jamhari ${ }^{2}$ \\ 1 Fakultas Pertanian Universitas Lampung \\ Jalan Sumantri Brojonegoro Nomor 1, Gedung Meneng, Bandar Lampung, Telepon +62-0721-781821 \\ 2 Fakultas Pertanian Universitas Gadjah Mada Yogyakarta \\ Sekip Unit I, Yogyakarta 55281 Indonesia Telepon: +62-274-519717
}

Diterima 19 Februari 2011 / Disetujui 17 Oktober 2011

\begin{abstract}
This study aims were, first to measure the level of farmers' willingness to pay the external cost to improve the environment and second, examine the determinant factors. The experiment was conducted in District Sumberjaya and Sekincau, West Lampung District during June-October 2009. Contingent Valuation Method (CVM) was used to answer the first purpose, while ordinal logit regression analysis was used to answer the second purpose. Factors of farmland area, land productivity, household income, educational level, number of family labor, and knowledge of farmers about the benefits of forests had positive influence on WTP while distance of farmers' house to the forest had negative influence. The increase of WTP was needed to reduce environmental damage due to forest conversion to coffee plantation; moreover, environment improvement hopefully could restore the function of forest where coffee trees were planted.
\end{abstract}

Keywords: willingness to pay, improving environment, coffee farmers, forest conversion

\begin{abstract}
Abstrak: Penelitian ini bertujuan, pertama, mengukur tingkat kesediaan membayar external cost petani kopi dalam rangka perbaikan lingkungan dan kedua, mengkaji faktor-faktor yang mempengaruhinya. Penelitian dilaksanakan di kecamatan Sumberjaya dan Sekincau, Kabupaten Lampung Barat pada bulan Juni-Oktober 2009. Untuk menjawab tujuan (1) diukur dengan metode CVM (Contingent Valuation Method) serta untuk menjawab tujuan (2) digunakan analisis regresi ordinal logit. Faktor-faktor yang dapat meningkatkan kesediaan membayar (WTP) adalah luas lahan usahatani, produktivitas lahan, pendapatan rumah tangga, tingkat pendidikan, jumlah tenaga kerja keluarga, dan pengetahuan petani tentang manfaat hutan, sedangkan jarak rumah petani ke hutan berpengaruh negatif. Peningkatan WTP perlu terus dilakukan untuk mengurangi kerusakan lingkungan akibat alih fungsi lahan hutan menjadi usahatani kopi dan bahkan diharapkan dapat mengembalikan fungsi hutan pada lahan yang ditanami kopi.
\end{abstract}

Kata kunci: willingness to pay, perbaikan lingkungan, petani kopi, alih fungsi hutan

\section{PENDAHULUAN}

Kopi merupakan salah satu komoditas andalan perkebunan di Lampung dan mempunyai peranan sebagai penghasil devisa negara, sumber pendapatan, penyedia lapangan kerja, dan mendorong perkembangan agribisnis dan agroindustri. Kabupaten Lampung Barat merupa- kan sentra produksi kopi di provinsi Lampung. Areal perkebunan kopi di kabupaten ini adalah $60.488,35$ ha atau 35,57 persen dari total areal di provinsi Lampung dengan produksi sebesar 38.422,6 ton dan produktivitasnya adalah 0,6352 ton/ha (Badan Pusat Statistik Lampung Barat, 2008).

Di Lampung Barat selain di tanah marga, 
kopi sebagian besar ditanam di kawasan hutan. Menurut Syam et al. (1997) peningkatan luas kebun kopi di Lampung berasal dari pembukaan hutan (60,2 persen), dari belukar ( 34,6 persen), dan dari ladang (5,2 persen). Alih guna lahan hutan menjadi lahan usahatani kopi telah menjadi perhatian karena dikhawatirkan dapat menimbulkan dampak serius terhadap pengrusakan fungsi hutan, penurunan produktivitas tanah pada khususnya dan degradasi lahan pada umumnya. Penelitian World Wildlife Fund (WWF) Indonesia (2005) menunjukkan kebun kopi merusak habitat dan konservasi alam karena merambah hutan lindung dan taman nasional. Menurut Widianto et al. (2004), fungsi hidrologis hutan tidak dapat digantikan dengan sistem kebun kopi monokultur.

Alih fungsi lahan hutan menjadi usahatani kopi di Lampung Barat terjadi di hutan lindung dan Taman Nasional Bukit Barisan Selatan (TNBBS). Hutan lindung di Sumberjaya merupakan hulu DAS Way Besay. Menurut Syam et al. (1997); Van Noordwijk et al. (2002; dan Verbist et al. (2005), konversi hutan menjadi kebun kopi di Sumberjaya menyebabkan jumlah luasan hutan di hulu DAS Way Besay Sumberjaya berkurang dari 60 persen (pada tahun 1970-an) menjadi 10 persen pada tahun 2000 dari total luas lahan. Pada periode yang sama luas perkebunan kopi meningkat dari 8 persen pada tahun 1970 menjadi 70 persen pada tahun 2000. Untuk hutan TNBBS, menurut Pasaribu (2007), telah terjadi kerusakan hutan TNBBS seluas 57.089 ha $(20,37$ persen) akibat perambahan hutan dengan jumlah perambah 16.522 kepala keluarga. Hutan rusak mayoritas dialihfungsikan menjadi kebun kopi. Aktifitas perambahan hutan yang luas di TNBBS terjadi di kecamatan Sekincau.

Untuk dapat menekan dampak negatif dari alih guna lahan hutan menjadi usahatani kopi, kebun kopi diarahkan ke sistem agroforestry (wanatani) yaitu dengan memadukan kegiatan pengelolaan hutan atau pohon kayu-kayuan dengan penanaman komoditas pertanian. Selain berfungsi produksi, sistem wanatani juga berfungsi jasa (service functions) terutama berkaitan dengan pengelolaan tanah (soil management), pengendalian erosi, serta pemeliharaan dan perbaikan kualitas tanah. Pohon kayukayuan pada sistem wanatani dapat berfungsi sebagai pohon pelindung atau naungan bagi pohon kopi. Menurut Hernandez-Martinez et al. (2009), perkebunan kopi dengan pohon pelindung akan membentuk suatu agroekosistem kopi yang mempunyai peranan penting dari aspek sosial, ekonomi, dan konservasi dan menurut Blackman et al. (2007) kopi bernaungan kompleks sebagai sistem agroforestri menyediakan ekosistem servis yang hampir sama dengan hutan meskipun pada level sedikit di bawah hutan.

Kopi bernaungan atau berpelindung merupakan salah satu ciri agroekosistem kopi berkelanjutan secara ekologi (RDV-The World Bank, 2002). Di samping itu salah satu persyaratan dalam berbagai program sertifikasi adalah adanya naungan pada kebun kopi (Kine, 2009; Mas and Dietsch, 2003). Di Lampung Barat tidak semua petani kopi menanam pohon kayukayuan atau pohon pelindung pada kebun kopinya. Hasil penelitian Prasmatiwi et al. (2010a) di Lampung Barat masih ada 16 persen petani kopi di kawasan hutan dan 33,33 persen petani luar kawasan yang belum menanam pohon naungan pada kebun kopinya.

Selain menanam pohon kayu-kayuan yang sekaligus berperan sebagai pohon pelindung kopi, penerapan teknologi konservasi diperlukan untuk mengelola usahatani kopi di kawasan hutan yang umumnya daerahnya berbukit, curam, dan terjal yaitu dengan menerapkan konservasi tanah dan air, konservasi biotik, serta pengurangan risiko usaha dengan diversifikasi. Namun penerapan konservasi tanah petani kopi masih rendah. Penerapan konservasi tanah usahatani kopi di kawasan hutan Lampung Barat adalah 50,13 persen dan untuk luar kawasan hutan 53,81 persen.

Untuk memperkecil dampak alih fungsi lahan hutan menjadi usahatani kopi petani kopi diharapkan dapat menekan kerusakan lingkungan melalui kesediaan membayar (Willingness to Pay WTP). Penghitungan WTP biasanya dikaitkan dengan peningkatan kualitas dan degradasi lingkungan yaitu dengan menghitung biaya yang bersedia dikeluarkan oleh individu untuk mengurangi dampak negatif pada 
lingkungan karena adanya suatu kegiatan pembangunan. Dengan demikian pengukuran apresiasi lingkungan diperlukan untuk mengetahui seberapa besar tingkat kesediaan membayar petani kopi dalam rangka perbaikan lingkungan. Berdasarkan permasalahan tersebut, penelitian ini bertujuan untuk (1) mengukur tingkat kesediaan membayar (WTP) petani kopi dalam rangka perbaikan lingkungan dan (2) mengkaji faktor-faktor apa saja yang mempengaruhinya.

Landasan Teori. Pemilikan, pemanfaatan, atau produksi suatu barang oleh seseorang sering menimbulkan eksternalitas atau dampak eksternal. Menurut Pyndick \& Rubinfeld (2001) eksternalitas didefinisikan sebagai dampak positif atau negatif (net cost atau benefit) dari tindakan satu pihak terhadap pihak lain. Dampak eksternal akibat konversi hutan menjadi lahan pertanian adalah bencana tata air dan lingkungan. Kerusakan lingkungan pada akhirnya harus dipikul dengan biaya yang cukup tinggi. Yang menjadi masalah adalah siapa yang harus menanggung biaya tersebut. Para ekonom berpendapat bahwa pihak yang menimbulkan kerugian harus dikenai kewajiban untuk mencegah pencemaran atau diwajibkan membayar pajak sebesar kerugian yang ditimbulkannya (Suparmoko, 2006). Cara mengatasi eksternalitas negatif adalah dengan menginternalisasikan biaya eksternal yaitu memperhitungkan semua biaya eksternal ke dalam perhitungan biaya produksi (Fauzi, 2004). Hal ini dipertegas oleh Irham (2005) bahwa setiap kegiatan ekonomi seharusnya melakukan proses internalizing external costs yaitu memperhitungkan biaya lingkungan atau nilai kerugian yang diderita oleh pihak lain sebagai salah satu komponen biaya produksi.

Cara pengukuran eksternalitas ke dalam nilai moneter adalah hal yang tidak mudah. Dengan demikian harus dicari pendekatan perhitungan untuk mengkuantifikasi dampak lingkungan yaitu valuasi ekonomi. Nilai ekonomi untuk suatu sumberdaya diukur berdasarkan jumlah nilai maksimum yang ingin dibayarkan seseorang untuk menikmati sumberdaya dengan mengalahkan mengkonsumsi sumberdaya yang lain. Dalam ekonomi pasar mata uang (currency) ukuran nilai ekonomi bersifat universal, sebab jumlah nilai yang ingin dibayarkan seseorang mencerminkan seberapa banyak barang dan jasa lain dikorbankan dalam rangka mendapatkan suatu barang dan jasa tertentu yang diinginkan. Konsep ini disebut willingness to pay (WTP). Penghitungan WTP dikaitkan dengan seberapa jauh kemampuan setiap individu atau masyarakat secara agregat untuk membayar atau mengeluarkan uang dalam rangka mengurangi dampak negatif atau memperbaiki kondisi lingkungan sesuai dengan standar yang diinginkannya (Pearce, et al, 1994).

Willingness to Pay (WTP) adalah harga maksimum yang konsumen ingin bayarkan terhadap barang dan jasa dan mengukur berapa nilai konsumen ingin bayarkan terhadap barang dan jasa atau dengan kata lain mengukur manfaat marjinal dari konsumen. Secara grafis WTP adalah area di bawah kurva permintaan. Surplus konsumen adalah WTP dikurangi jumlah yang dibayarkan atau jumlah yang ingin dibayarkan oleh konsumen dikurangi dengan jumlah yang secara aktual dibayarkan oleh konsumen, lihat Gambar 1.

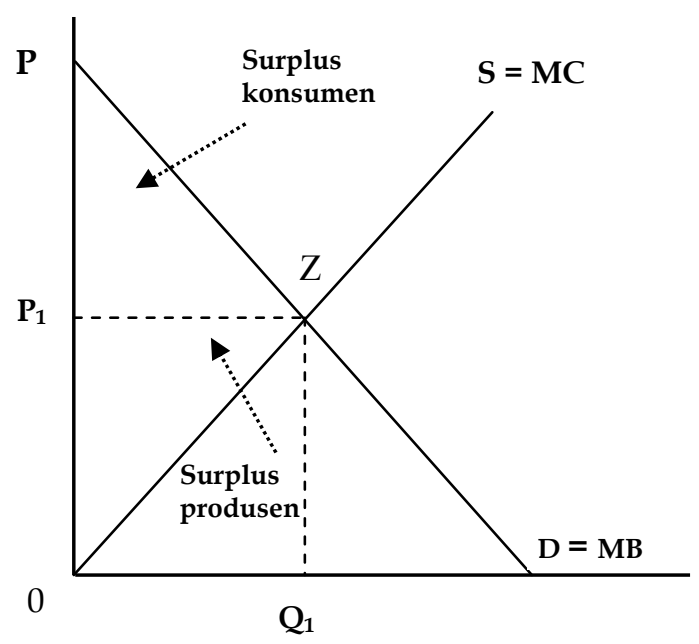

Keterangan: $\mathrm{WTP}=0 \mathrm{PZQ}_{1}, \mathrm{PZ0}$ adalah Manfaat Sosial Bersih, $\mathrm{PZP}_{1}$ adalah surplus konsumen, dan $\mathrm{P}_{1} \mathrm{Z} 0$ adalah surplus produsen

Gambar 1. Surplus Konsumen dan Surplus Produsen (Besanko et al., 2000)

Adapun surplus produsen adalah jumlah yang dibayarkan oleh produsen dikurangi biaya produksi. Surplus produsen menggambarkan manfaat yang diterima produsen ketika 
terlibat di pasar. Suplai pasar menggambarkan biaya marjinal untuk memproduksi barang dan jasa, sedangkan permintaan pasar menggambarkan marginal benefit dari mengkonsumsi barang dan jasa. Net Social Benefit atau surplus pasar adalah selisih antara manfaat yang diperoleh masyarakat dari memproduksi sumber daya alam dan biaya yang dikeluarkan untuk memproduksinya.

Efisiensi terjadi di titik $Z$ yaitu ketika kesempatan yang membuat seseorang menjadi lebih sejahtera tidak membuat orang lain berkurang kesejahteraannya dan dikenal dengan Pareto efficiency. Titik optimal terjadi pada saat manfaat sosial bersih (Net Social Benefit NSB) maksimum yaitu MC=MB. (Gambar 1) Permintaan pasar menunjukkan WTP terhadap setiap unit barang dan jasa. Dalam pasar persaingan sempurna $\mathrm{P}=\mathrm{MC}=\mathrm{MB}$ dengan demikian persaingan sempurna menggambarkan kondisi yang efisien. Pada kasus terjadi eksternalitas dimana aktivitas pelaku pasar mempengaruhi kesejahteraan pihak lain tidak dapat dicerminkan oleh harga pasar maka akan menyebabkan pasar tidak efisien.

Secara garis besar metode penilaian manfaat suatu sumberdaya alam dan lingkungan dapat dibagi berdasarkan pendekatan yang berorientasi pasar yaitu jika penilaian sumberdaya menggunakan harga pasar aktual barang dan jasa dan teknik penilaian nonpasar jika sumberdaya alam tidak dapat dipasarkan. Menurut Fauzi (2004) teknik penilaian ekonomi sumberdaya yang tidak dipasarkan digolongkan menjadi dua pendekatan yaitu (1) pendekatan tidak langsung atau revealed Willingness To Pay (WTP) (keinginan membayar terungkap) misalnya menggunakan metode travel cost, hedonic pricing, dan random utility model; (2) pendekatan langsung atau survai misalnya dengan Contingent Valuation Method (CVM), Random Utility Model, dan Contingent Choice

Dalam penelitian ini metode pendekatan yang digunakan adalah dengan CVM. Metode CVM digunakan untuk menilai ekonomi barang publik dengan menanyakan langsung kepada pengguna jasa lingkungan seberapa besar maksimum kesediaan membayar sebagai kompensasi akibat kerusakan lingkungan. Kesedian membayar merupakan gambaran dari tingkat preferensi dan pendapatan individu (Pearce et al, 1994). Dengan demikian metode CVM ini diharapkan dapat menentukan preferensi responden terhadap barang sumber daya alam dengan mengemukakan kesanggupan untuk membayar atau WTP yang dinyatakan dalam bentuk nilai uang.

Pendekatan CVM mulai populer pada tahun 1970-an. Pendekatan ini disebut contingent (tergantung) karena pada praktiknya informasi yang diperoleh sangat tergantung pada hipotesis yang dibangun. Besarnya WTP merupakan ungkapan kesatuan dari deskripsi peneliti terhadap perubahan suatu provisi sumberdaya dan dengan cara bagaimana seseorang dapat membayar untuk mendapatkan atau menghindari perubahan tersebut. CVM bertujuan untuk mengetahui keinginan membayar (WTP) dari suatu masyarakat dan keinginan menerima (WTA) kerusakan suatu lingkungan.

Untuk memperoleh hasil yang maksimal, penggunaan metode CVM ini diperlukan desain kuisioner yang baik. Terdapat 4 macam desain kuesioner yang umum digunakan yakni (1) Metode pertanyaan langsung ('direct question" method/open ended), yaitu dengan cara memberikan pertanyaan langsung berapa harga yang sanggup dibayarkan oleh responden untuk dapat memanfaatkan atau mengkonsumsi lingkungan yang ditawarkan. (2) Metode penawaran bertingkat ("bidding game" method). Caranya dengan menetapkan sebuah harga "tertentu' telah ditetapkan oleh pewawancara kemudian ditanyakan kepada responden apakah harga tersebut layak. Jika responden menjawab "ya" dengan harga yang ditawarkan maka harga dinaikkan terus hingga responden menjawab "tidak". Angka terakhir yang dicapai tersebut merupakan nilai WTP yang tertinggi. Hal yang sebaliknya bisa juga terjadi yaitu jika responden menjawab "tidak" untuk harga pertama yang ditawarkan. Jika demikian yang terjadi maka harga diturunkan terus hingga responden menjawab "ya". Angka terakhir yang dicapai tersebut dianggap sebagai nilai WTP ini dianggap sebagai harga/nilai barang lingkungan yang ditawarkan. (3) Metode kartu pembayaran ("payment card" method). Metode ini digu- 
nakan dengan bantuan sebuah kartu berisi daftar harga yang dimulai dari nol (0) sampai pada suatu harga tertentu yang relatif tinggi. Kemudian kepada responden ditanyakan harga maksimum sanggup membayar untuk suatu produk sumber daya alam. dan (4) metode setuju atau tidak setuju ("take it or leave"Method). Dari sudut responden metode ini sangat mudah karena responden ditawari sebuah harga, kemudian ditanya, setuju atau tidak dengan harga tesebut.

\section{METODE PENELITIAN}

\section{Lokasi dan Sampel Penelitian}

Penelitian dilaksanakan di kabupaten Lampung Barat. Kemudian diambil dua kecamatan (1) kecamatan Sumberjaya yang merupakan hulu DAS Way Besay yang dalam tiga dasa warsa terakhir konversi hutan menyebabkan jumlah luasan hutan di hulu DAS Way Besay berkurang dari 60 persen (pada tahun 1970-an) menjadi 12 persen pada tahun 2000 dari total luas lahan. (2) Kecamatan Sekincau dimana di kecamatan tersebut terdapat TNBBS serta TNBBS di Sekincau mengalami kerusakan hutan dan alih fungsi hutan menjadi perkebunan kopi yang tinggi. Di kedua kecamatan tersebut merupakan sentra perkebunan kopi di Lampung Barat. Untuk masing-masing kecamatan diambil 50 petani kopi yang mengusahakan kopi di kawasan hutan dan 30 petani yang mengusahakan kopi di luar kawasan hutan yang diambil secara acak. Waktu pengambilan data adalah bulan Juni-Oktober 2009.

Teknik wawancara untuk mengetahui kesediaan membayar (WTP) petani kopi untuk perbaikan lingkungan menggunakan kombinasi pendekatan terbuka (open ended) dan close-ended CVM (Contingent Valuation Method) dengan berusaha menggali kesediaan responden untuk membayar secara individu. Dalam pendekatan close ended CVM digunakan discrete choice untuk menanyakan kepada responden menerima atau menolak sebuah harga yang ditawarkan pada sebuah pasar hipotesis melalui estimasi yang sudah ditetapkan sebelumnya (Bishop dan Heberlein, 1979). Jika responden menjawab "ya" nilai dicatat. Penawaran mulai dari nol rupiah sampai dengan yang tertinggi.

\section{Definisi Variabel}

(1) Kesediaan membayar (Willingnes to Pay) petani kopi dalam rangka perbaikan lingkungan dilakukan melalui estimasi kesediaan petani mengeluarkan biaya untuk perbaikan lingkungan yaitu untuk perbaikan teknis konservasi tanah, penambahan pohon naungan, pembayaran pajak lingkungan, dan kegiatan reboisasi. Besar estimasi dalam satuan rupiah.

(2) Luas lahan kopi adalah luas lahan yang diusahakan untuk menanam kopi (ha).

(3) Produktivitas lahan adalah total produksi seluruh tanaman yang ditanam yang meliputi produksi kopi, tanaman naungan, maupun tanaman yang lain yang ditanam pada sebidang lahan dan dihitung disetarakan dengan produksi kopi diukur dengan kg setara kopi kering giling/ha.

(4) Pendapatan rumah tangga adalah pendapatan rumah tangga baik berasal dari pertanian maupun non pertanian. Diukur dalam satuan rupiah pertahun ( $\mathrm{Rp} / \mathrm{thn})$.

(5) Jarak tempat tinggal dengan hutan adalah jarak tempat rumah atau tempat tinggal petani dengan kawasan hutan yang terdekat $(\mathrm{m})$.

(6) Pendidikan petani adalah adalah tingkat pendidikan formal yang pernah ditempuh oleh petani kopi (thn).

(7) Umur petani adalah umur petani saat dilakukan penelitian yang diukur dalam satuan tahun (thn).

(8) Pengetahuan petani tentang manfaat hutan: adalah pengetahuan petani tentang manfaat dan fungsi hutan diukur dengan skor.

(9) Jumlah tenaga kerja keluarga adalah jumlah tenaga kerja yang tersedia dalam keluarga yang diukur dalam jumlah orang (jiwa).

(10) Kemiringan lahan adalah kemiringan lereng lahan yang diusahakan untuk usahatani kopi menurut persepsi petani. Kemiringan lahan dibedakan menjadi dua yaitu lahan miring $(D=1$ jika menurut persepsi petani lahannya mempunyai kemiringan $>30 \%$ dan $\mathrm{D}=0$ jika lahannya menurut persepsi petani mempunyai kemiringan $<30 \%$.

(11) Status petani (D3), adalah status petani 
kopi di tempat penelitan. D3=1 untuk penduduk lokal (jika sejak lahir sudah bertempat tinggal di daerah penelitian dan D3=0 untuk lainnya).

(12) Lokasi lahan dibedakan menjadi dua yaitu Sumberjaya dan Sekincau. Merupakan dummy variabel $\mathrm{D}=1$ untuk Sumberjaya dan $\mathrm{D}=0$ untuk lainnya.

(13) Pekerjaan sampingan dibedakan menjadi dua yaitu petani mempunyai pekerjaan sampingan di luar usahatani dan petani tidak mempunyai pekerjaan selain usahatani.

\section{Metode Analisis}

Untuk mengetahui faktor-faktor yang mempengaruhi kesediaan membayar (WTP) petani kopi dalam rangka perbaikan lingkungan digunakan Analisis Regresi Ordinal Logit (Ordinal Logistic Regression atau Ologistik). Model Ologistik variabel tidak bebasnya merupakan variabel yang memiliki skala ordinal dengan level sebanyak 3 atau lebih (Greene, 2002. Misal terdapat Di pilihan individu, dimana Di merupakan fungsi linear dari faktor $\mathrm{K}$ (determining variables) untuk individu i dan Xik, $\mathrm{k}=1, \ldots \mathrm{K}$ maka persamaan dapat ditulis sebagai berikut (Borooah, 2002):

$$
D i=\sum_{k=1}^{K} \beta k X i k+\varepsilon i=Z i+\varepsilon i
$$

dimana $ß \mathrm{k}$ adalah koefisien dengan variable $\mathrm{k}$ $(\mathrm{k}=1, \ldots, \mathrm{K})$ dan $Z i=\sum_{k=1}^{K} \beta k X i k$. Variabel k terdiri dari karakteristik individu dan karakteristik pilihan (atribut). Peningkatan nilai faktor $\mathrm{k}$ akan menyebabkan pilihan individu meningkat jika $\$ \mathrm{k}>0$ dan menurun jika $1 \mathrm{k}<<0$. Di diklasifikasikan berdasarkan rangking/kategori ordinal (Yi) dengan persamaan:

$$
\begin{aligned}
& Y i=1, \text { jika } D i \leq \delta 1 \\
& Y i=2, \text { jika } \delta 1<D i \leq \delta 2 \\
& Y i=3, \text { jika } D i>\delta 2
\end{aligned}
$$

dimana $\delta 1, \delta 2 \geq 0$ dari persamaan adalah unknown parameters $(\delta 1<\delta 2)$ untuk mengestimasi sk pada persamaan. Probabilitas Yi merupakan nilai 1, 2, dan 3 adalah:

$$
\begin{aligned}
\operatorname{Pr}(Y \mathrm{i}=1)= & \operatorname{Pr}(\mathrm{Zi}+\varepsilon \mathrm{i} \leq \delta 1)=\operatorname{Pr}(\varepsilon \mathrm{i} \leq \delta 1-\mathrm{Zi}) \\
\operatorname{Pr}(\mathrm{Yi}=2)= & \operatorname{Pr}(\delta 1<\mathrm{Zi}+\varepsilon \mathrm{i} \leq \delta 2=\operatorname{Pr}(\delta 1-\mathrm{Zi}<\varepsilon \mathrm{i} \\
& \leq \delta 2-\mathrm{Zi}) \\
\operatorname{Pr}(\mathrm{Yi}=3)= & \operatorname{Pr}(\mathrm{Zi}+\varepsilon \mathrm{i}>\delta 2)=\operatorname{Pr}(\varepsilon \mathrm{i}>\delta 1-\mathrm{Zi})
\end{aligned}
$$

Lebih lanjut persamaan model logit atau fungsi logistik probabilitas kumulatif adalah:

$$
\begin{aligned}
\mathrm{Pi}=\mathrm{F}(\mathrm{Zi}) & =\mathrm{F}(\alpha+\beta \mathrm{Xi}) \\
& =1 /\left(1+e^{-z}\right)=1 /\left(1+e^{-\left(\alpha+\beta X_{i}\right)}\right)
\end{aligned}
$$

Jika kedua sisi persamaan (1) dikalikan dengan $1+$ didapat:

$$
\left(1+e^{-Z_{i}}\right) P_{i}=1
$$$$
e^{-Z_{i}}=1 / \mathrm{Pi}-1=\frac{1-P_{i}}{P_{i}}
$$

Karena $e^{-Z_{i}}=1 / e^{Z_{i}}$ maka

$e^{Z_{i}}=\frac{P_{i}}{1-P_{i}}($ odd ratio $)$

$\log \frac{P_{i}}{1-P_{i}}=\mathrm{Zi}=\mathrm{a}+\beta \mathrm{Xi}$ ) (bentuk log dari odd ratio)

e adalah bilangan natural dengan nilai 2,718

$\mathrm{Pi}$ adalah probabilitas dimana individu akan memilih suatu pilihan pada Xi tertentu, terletak antara 0 dan 1 dan $P$ adalah non linear terhadap Z. Berdasar perhitungan, besar WTP kemudian diurutkan dari nilai tertinggi sampai terendah dan dibuat dalam 5 rangking. Skor 5 (tertinggi) menunjukkan apresiasi petani kopi terhadap lingkungan sangat tinggi dan skor 1 (terendah) menunjukkan apresiasi petani kopi terhadap lingkungan sangat rendah. Dengan demikian variabel terikat $Y$ memiliki 5 level/ jenjang dan satu yang dijadikan sebagai reference event atau kontrol, sehingga didapatkan 4 model regresi. Probabilitas kesediaan petani membayar (WTP) untuk perbaikan lingkungan dinyatakan sebagai $\mathrm{P} 1=\mathrm{P}(\mathrm{Y}=1), \mathrm{P} 2=\mathrm{P}(\mathrm{Y}=2), \mathrm{P} 3=\mathrm{P}(\mathrm{Y}=3), \mathrm{P} 4=$ $\mathrm{P}(\mathrm{Y}=4)$, dan $\mathrm{P} 5=\mathrm{P}(\mathrm{Y}=5)$.

Persamaan kesediaan petani membayar (WTP) untuk perbaikan lingkungan sebagai berikut,

$Y=\alpha+\beta_{1} X_{1}+\beta_{2} X_{2}+\beta_{3} X_{3}+\beta_{4} X_{4}+\beta_{5} X_{5}+$ 


$$
\begin{aligned}
& \beta_{6} X_{6}+\beta_{7} X_{7}+\beta_{8} X_{8}+\beta_{9} X_{9}+d_{1} D_{1}+ \\
& d_{2} D_{2}+d_{3} D_{3}+d_{4} D_{4}+\mu
\end{aligned}
$$

dimana: $\mathbf{Y}$ adalah Tingkat kesediaan membayar WTP external cost (skala ordinal 1 sd 5); $\mathbf{X}_{\mathbf{1}}$ adalah luas lahan garapan kopi (ha); $\mathbf{X}_{\mathbf{2}}$ adalah Produktivitas total lahan (kg setara kopi/ha); $\mathbf{X}_{3}$ adalah Pendapatan rumah tangga (Rp/tahun); $\mathbf{X}_{\mathbf{4}}$ adalah Jarak tempat tinggal dengan hutan $(\mathrm{m}) ; \mathbf{X}_{\mathbf{5}}$ adalah Pendidikan petani (tahun); $\mathbf{X}_{\mathbf{6}}$ adalah Umur petani (thn); $\boldsymbol{X}_{7}$ adalah Pengetahuan petani tentang manfaat hutan (skor); $\mathbf{X}_{8}$ adalah Jumlah tenaga kerja keluarga (jiwa); $\mathbf{D}_{\mathbf{1}}$ adalah kemiringan lahan $\left(D_{1}=1\right.$ miring dan $\mathrm{D}_{1}=0$ ) untuk lainnya; $\mathbf{D}_{2}$ adalah Status petani $\left(\mathrm{D}_{2}=1\right.$ penduduk asli dan $\mathrm{D}_{2}=0$ untuk lainnya); $\mathrm{D}_{3}$ adalah Pekerjaan sampingan $\left(\mathrm{D}_{3}=1\right.$ punya pekerjaan sampingan dan $\mathrm{D}_{3}=0$ untuk lainnya; $\mathrm{D}_{4}$ adalah Lokasi $\left(\mathrm{D}_{4}=1\right.$ untuk Sumberjaya, $\mathrm{D}_{4}=0$ untuk lainnya)

\section{HASIL DAN PEMBAHASAN}

\section{Kesediaan Membayar (WTP) Petani Kopi}

Dalam rangka menekan kerusakan lingkungan akibat alih fungsi lahan hutan menjadi usahatani kopi petani kopi diharapkan bersedia mengeluarkan biaya tiap tahunnya untuk memperbaiki bangunan konservasi tanah, menambah atau mengganti tanaman naungan yang mati, membayar pajak lingkungan, serta kegiatan rehabilitasi hutan maupun lahan kritis. Kesediaan petani membayar (WTP) akan meninkatkan keberlanjutan usahatani kopi serta dapat memenuhi persyaratan sertifikasi kopi. Namun hasil analisis menunjukkan tidak semua petani bersedia membayar (WTP) untuk perbaikan lingkungan seperti disajikan pada Tabel 1.
Tidak semua petani bersedia membayar (WTP) untuk perbaikan bangunan konservasi tanah. Sebesar 15 persen petani kopi di kawasan hutan dan 16,67 persen petani di luar kawasan tidak bersedia untuk memperbaiki bangunan konservasi tanah dengan alasan tidak mempunyai tenaga dan biaya. Khusus untuk petani kopi di Taman Nasional Bukit Barisan Selatan (TNBBS) Sekincau, petani tidak bersedia membayar WTP untuk membuat bangunan konservasi tanah karena bangunan konservasi tanah membutuhkan biaya yang mahal, sedang tidak ada kepastian usaha di TNBBS. Kawasan TNBBS adalah kawasan konservasi yang tidak diperbolehkan untuk kegiatan usahatani sehingga para petani kopi di TNBBS adalah para perambah hutan.

Hasil penelitian Prasmatiwi et al (2010a) dan Prasmatiwi et al $\left(2010^{\mathrm{b}}\right)$ menyatakan bahwa produktivitas lahan dan pendapatan kebun kopi berpenaung lebih tinggi dan lebih berkelanjutan dibanding kebun kopi tanpa naungan. Namun, 58 persen petani kawasan hutan dan 57,67 persen petani luar kawasan hutan tidak bersedia membayar WTP untuk menambah tanaman naungan. Sebesar 30 persen petani kopi di kawasan hutan dan 25 persen petani kopi luar kawasan mengalami kesulitas mencari bibit tanaman naungan yang berupa tanaman kayu-kayuan dan buah-buahan yang berkualitas. Kalaupun bibit tersedia di pasar, kualitasnya kurang bagus sehingga mati jika ditanam. Sebagian petani beranggapan bahwa jumlah naungan sudah cukup dan sudah sesuai dengan SK Bupati Lampung Barat No. 11/2004 yaitu mewajibkan anggota kelompok HKm menanam minimal 400 batang per hektar pepohonan berjenis kayu dan buah selain tanaman kopi.

Tabel 1. Kesediaan Petani Membayar (WTP) untuk Memperbaiki Lingkungan

\begin{tabular}{lcccc}
\hline \multirow{2}{*}{ Aktivitas } & \multicolumn{2}{c}{ Bersedia membayar (\%) } & \multicolumn{2}{c}{ Tidak bersedia membayar (\%) } \\
\cline { 2 - 5 } & Kawasan hutan & Luar kawasan & Kawasan hutan & Luar kawasan \\
\hline Perbaikan konservasi tanah & rrsid3487445 85,00 & 83,33 & 15,00 & 16,67 \\
Penanaman pohon naungan & 42,00 & 42,33 & 58,00 & 57,67 \\
Reboisasi, penghijauan & 88,00 & 76,66 & 12,00 & 23,34 \\
Pajak lingkungan & 92,00 & 86,67 & 8,00 & 13,33 \\
\hline
\end{tabular}


Sehubungan dengan kegiatan memelihara dan merehabilitasi hutan, 92 persen petani di kawasan hutan dan 96 persen petani di luar kawasan menyatakan setuju jika pemerintah menarik pajak lingkungan. Dengan banyaknya petani yang bersedia membayar pajak lingkungan dapat digunakan untuk segera merealisasikan Peraturan Daerah No. 7 tahun 2000 tentang Retribusi Izin Pemungutan terhadap Pengambilan Hasil Hutan Bukan Kayu di Kawasan Hutan. Perda No. 7 tahun 2000 memberikan landasan hukum dan arah pada kelompok masyarakat pengguna hutan termasuk anggota $\mathrm{HKm}$ yang mendapatkan manfaat dari hasil kawasan hutan melalui pembayaran retribusi yang mana dana tersebut akan dipergunakan kembali untuk pemulihan fungsi hutan. Perda tersebut belum efektif dilaksanakan di tingkat anggota $\mathrm{HKm}$. Sebesar 8 persen petani kopi di kawasan hutan dan 4 persen petani di luar kawasan tidak setuju jika pemerintah menarik pajak lingkungan dengan alasan tidak ada modal.

Besar kesediaan petani membayar (WTP) dalam rangka perbaikan lingkungan disajikan pada Tabel 2.

Tidak ada perbedaan yang nyata ( $\mathrm{t}$ hitung $0,657)$ kesediaan petani membayar (WTP) untuk perbaikan lingkungan antara petani kawasan hutan Lampung Barat (Rp484.590/tahun) dan petani luar kawasan (Rp405.036/tahun).
Hal ini karena petani kopi yang mempunyai lahan kopi di kawasan hutan maupun petani yang mempunyai lahan di luar kawasan hutan sudah membaur satu sama lain, dan telah mengikuti kegiatan penyuluhan pertanian.

Kesediaan membayar untuk perbaikan konservasi tanah merupakan komponen WTP yang dikeluarkan paling besar. Perbaikan bangunan konservasi tanah di antaranya dilakukan dengan jalan memperbaiki bangunan teras, menanam tanaman penguat teras, penanaman tanaman penutup tanah, perbaikan gulud dan rorak. Aktivitas pembuatan teras mengeluarkan biaya yang paling tinggi. Hal ini karena hanya 28 persen petani yang membangun teras pada lahannya, kalaupun ada bangunan teras, teras dibangun semi permanen yang tidak diberi baungunan penguat teras dengan batu seperti disajikan pada Tabel 3. Hasil uji t (t hitung 1,127 dan tingkat signifikansi 0,261) menunjukkan tidak ada perbedaan besar WTP untuk perbaikan konservasi tanah antara petani kawasan hutan (Rp384.115/tahun) dengan petani luar kawasan (Rp323.500/tahun).

Walaupun jumlah naungan yang ditanam petani kopi di kawasan hutan lebih banyak dibanding petani kopi di luar kawasan hutan (Tabel 4), namun hasil uji $\mathrm{t}(\mathrm{t}$ hitung 0,255$)$ menunjukkan tidak ada perbedaan besar WTP untuk menambah tanaman naungan antara petani

Tabel 2. Besar Kesediaan Membayar (WTP) Petani Kopi dalam Rangka Perbaikan Lingkungan

\begin{tabular}{lrr}
\hline Aktivitas & WTP kawasan hutan (Rp) & WTP luar kawasan hutan (Rp) \\
\hline 1. Perbaikan kons. tanah & & $220.875,50$ \\
- Bangunan teras & $187.575,00$ & $12.166,50$ \\
- Tnm penguat teras & $27.145,00$ & $5.000,00$ \\
- Penanam searah kontur & $30.040,00$ & $4.000,00$ \\
- Tnm penutup tnh & $22.095,00$ & $33.750,00$ \\
- gulud & $45.145,00$ & $47.708,00$ \\
- Rorak & $72.115,00$ & $323.500,00$ \\
Jumlah (1) & $384.115,00$ & \\
2. Penanaman naungan & & $6.333,50$ \\
-gliriside & $10.100,00$ & 167,50 \\
-dadap & $1.500,00$ & $20.256,00$ \\
-kayu2-an & $11.465,00$ & $7.810,00$ \\
-buah-buahan & $18.700,00$ & $34.567,00$ \\
Jumlah (2) & $41.765,00$ & $36.802,00$ \\
3. Reboisasi,penghijauan & $46.530,00$ & $10.167,00$ \\
4.Pajak lingkungan & $12.180,00$ & $405.036,00$ \\
Total WTP (1 sd 4) & $484.590,00$ & \\
\hline
\end{tabular}


Tabel 3. Kondisi Penerapan Konservasi Tanah oleh Petani Kopi di Lampung Barat

\begin{tabular}{|c|c|c|c|}
\hline \multicolumn{2}{|c|}{ Jenis Konservasi tanah } & \multicolumn{2}{|c|}{ Jumlah petani (\%) } \\
\hline & & kawasan hutan & luar kawasan hutan \\
\hline \multicolumn{4}{|c|}{ 1. Bangunan teras } \\
\hline & - Bangunan dari batu & 2 & 0 \\
\hline & - Bangunan dari tanah & 26 & 25 \\
\hline & - Tidak ada & 72 & 75 \\
\hline \multicolumn{4}{|c|}{ 2. Tanaman penguat teras } \\
\hline & - Menanam tanaman penguat teras & 17 & 12 \\
\hline & - Tidak menanam & 83 & 88 \\
\hline \multicolumn{4}{|c|}{ 3. Menanam searah kontur } \\
\hline & - Semua tanaman searah kontur & 40 & 42 \\
\hline & - Sebagian searah kontur & 14 & 18 \\
\hline & - $\quad$ Tidak searah kontur & 46 & 42 \\
\hline \multicolumn{4}{|c|}{ 4. Tanaman penutup tanah } \\
\hline & - Menanam penutup tanah & 10 & 17 \\
\hline & - $\quad$ Tidak menanam & 90 & 83 \\
\hline \multicolumn{4}{|c|}{ 5. Bangunan Gulud } \\
\hline & - Ada bangunan gulud & 39 & 17 \\
\hline & - $\quad$ Tidak ada & 61 & 83 \\
\hline \multicolumn{4}{|c|}{ 6. Bangunan Rorak } \\
\hline & Ada bangunan rorak & 46 & 55 \\
\hline & - $\quad$ Tidak ada & 54 & 45 \\
\hline
\end{tabular}

kawasan hutan (Rp41.765/tahun) dengan petani luar kawasan (Rp34.567/tahun).

Jumlah naungan yang ditanam petani di kawasan hutan terutaman hutan lindung lebih banyak dibanding luar kawasan hutan. Petani kopi di kawasan hutan Sumberjaya merupakan petani anggota kelompok HKm. Melalui kelompok $\mathrm{HKm}$, pemerintah memberikan hak penguasaan lahan dalam bentuk izin kelola HKm atas areal yang selama ini telah dikelola. Pada program $\mathrm{HKm}$ masyarakat mengintegrasikan berbagai jenis tanaman kayu dan tanaman nonkayu serta tanaman setahun dengan prinsip konservasi. Hasil penelitian Pender et al. (2008) menyimpulkan bahwa program $\mathrm{HKm}$ memberi kontribusi dalam menaikkan penanaman kayukayuan dan MPTS (Multi Purpose Tree SpeciesMPTS atau tanaman multiguna atau pepohonan berjenis kayu dan buah) pada kebun kopinya. Keanggotaan $\mathrm{HKm}$ selalu dievaluasi dan jika tidak mematuhi peraturan maka keanggotaan akan dicabut.

Petani bersedia mengeluarkan biaya untuk kegiatan reboisasi hutan yaitu rata-rata Rp46.530,00 untuk petani kopi di kawasan hutan dan Rp36.802,00 untuk petani luar kawasan hutan. Khusus untuk kawasan hutan lindung Sumberjaya, para petani anggota $\mathrm{HKm}$ mempunyai tanggung jawab untuk memelihara hutan lindung di sekitar lokasi kebun kopinya.

Tabel 4. Jumlah dan Jenis Tanaman Naungan per Hektar pada Kebun Kopi di Lampung Barat

\begin{tabular}{lcc}
\hline Jenis Tanaman Naungan & \multicolumn{2}{c}{ Jumlah Tanaman Naungan } \\
\cline { 2 - 3 } & Kawasan Hutan & Luar Kawasan Hutan \\
\hline Dadap & 50 & 40 \\
Gliriside & 177 & 154 \\
Tanaman Kayu-kayuan & 50 & 37 \\
Tanaman MPTS/Multiguna & 46 & 43 \\
Jumlah & $\mathbf{3 2 2}$ & $\mathbf{2 7 3}$ \\
\hline
\end{tabular}


Di samping itu kegiatan gotong royong memelihara hutan maupun lahan kritis di Sumberjaya maupun Sekincau lazim dilakukan oleh masyarakat baik yang punya lahan kopi di hutan maupun tidak. Oleh karena itu petani di luar kawasan hutan juga bersedia untuk membayar (WTP) untuk memperbaiki lingkungan.

\section{Faktor-faktor yang Mempengaruhi Kesedia- an Membayar (WTP) External Cost}

Untuk mengetahui faktor-faktor vang mempe-
Petani kopi di kawasan hutan mempunyai probabilitas tertinggi (30,99 persen) untuk membayar WTP pada range 4 (range WTP Rp1.125.001-Rp1.500.000). Petani kopi di kawasan hutan terus berusaha untuk memperbaiki lingkungan dengan jalan membayar WTP supaya tetap diizinkan untuk mengelola kawasan serta untuk meningkatkan keberlanjutan usahatani kopi di kawasan hutan. Petani di luar kawasan mempunyai probabilitas tertinggi membayar WTP pada range 3 (range 450.000Petani di luar kaP untuk perbaiklahan di daerah in bergelombang l. Di samping itu, P untuk perbaikh dan menanam n ini merupakan opi.

variabel secara uji Z. Luas lahan ndapatan rumah Iuan hutan, dan luarga berpengadiaan membayar asan hutan mauak rumah petani

atani kopi berpediaan membayar lokasi penelitian. ih luas biasanya empunyai modal r probabilitasnya lebih tinggi. Di Ihnya luas lahan membayar WTP pada berbagai kategori disajikan pada Tabel 7.
Illaka penuapalan pelaı akan naik dan akan mendorong petani memperbesar kesediaannya

Tabel 5. Range Besar WTP Petani Kopi

\begin{tabular}{ccc}
\hline Kategori (Skor) WTP & \multicolumn{2}{c}{ Range besar WTP (Rp/tahun) } \\
\cline { 2 - 3 } & Kawasan hutan & Luar kawasan \\
\hline 1 & $\leq 375.000$ & $<225.000$ \\
2 & $375.001-750.000$ & $225.000-450.000$ \\
3 & $750.001-1.125 .000$ & $450.000-675.000$ \\
4 & $1.125 .001-1.500 .000$ & $675.000-900.000$ \\
5 & $>1.500 .000$ & $>900.000$ \\
\hline
\end{tabular}


Tabel 6. Model Regresi Ordinal Logit Faktor-faktor yang Mempengaruhi Besar Kesediaan Membayar (WTP)

\begin{tabular}{|c|c|c|c|c|c|c|}
\hline \multirow[t]{2}{*}{ Variabel } & \multicolumn{3}{|c|}{ Kawasan hutan } & \multicolumn{3}{|c|}{ Luar kawasan hutan } \\
\hline & Estimate & Z-stat & OR & Estimate & Z-stat & OR \\
\hline Konstanta 1 & $10,2689^{* * *}$ & 3,7659 & & $6,2235^{*}$ & 1,6252 & \\
\hline Konstanta 2 & $12,2190 * * *$ & 4,3593 & & $8,9398^{* *}$ & 2,2905 & \\
\hline Konstanta 3 & $13,9521^{* * *}$ & 4,7977 & & $13,2056^{* * *}$ & 3,0768 & \\
\hline Konstanta 4 & $15,2334^{\star * *}$ & 4,9834 & & $17,1630^{* * *}$ & 3,6602 & \\
\hline Luas lahan & $0,4260^{*}$ & 1,7661 & 1,5311 & $0,1512 *$ & 1,9040 & 1,1632 \\
\hline Produktivitas lahan & $0,0010^{*}$ & 1,7116 & 1,0010 & $0,0006^{*}$ & 1,7958 & 1,0006 \\
\hline Pendapatan RT & $0,0000^{* *}$ & 2,1238 & 1,0000 & $0,00001^{* *}$ & 2,1215 & 1,0000 \\
\hline Jarak ke hutan & $-0,0001^{*}$ & $-1,8578$ & 0,9999 & $-0,0010^{* * *}$ & $-3,6852$ & 0,9990 \\
\hline Pendidikan & $0,2135^{* *}$ & 2,2080 & 1,2380 & $0,0044^{*}$ & 1,8295 & 1,0044 \\
\hline Umur petani & 0,0113 & 0,5139 & 1,0113 & 0,0261 & 0,6218 & 1,0264 \\
\hline Pengetahuan hutan & $0,0968 * *$ & 2,1451 & 1,1016 & 0,1420 ** & 1,9686 & 1,1526 \\
\hline Jml Tenaga kerja kel. & $0,4796^{* *}$ & 2,1996 & 1,6154 & $0,7472^{* *}$ & 2,3055 & 2,1111 \\
\hline Kemiringan lahan & 0,3932 & 0,8984 & 1,4818 & $1,3935^{*}$ & 1,8770 & 4,0289 \\
\hline Status petani & 0,7864 & 1,1780 & 2,1955 & $-0,4628$ & $-0,3786$ & 0,6295 \\
\hline Pekerjaan sampingan & $0,9205^{* *}$ & 1,9631 & 2,5104 & $-0,9106$ & $-1,3266$ & 0,4023 \\
\hline Lokasi & 0,0424 & 0,0663 & 1,0433 & $-0,4403$ & $-0,4959$ & 0,6438 \\
\hline LR index (Pseudo-R²) & 0,3665 & & & 0,5244 & & \\
\hline LR statistic (12 df) & $31,4371^{* * *}$ & & & $90,8269^{* * *}$ & & \\
\hline
\end{tabular}

Keterangan: ${ }^{* * *}$ : signifikan pada a $1 \% ; * *$ signifikan pada a $5 \%$; dan ${ }^{*}$ signifikan pada a $10 \%$. OR = odds ratio

nemahami pak negatani akan untuk mekerja daterhadap tuk mempenelitian. sesar akan erja dalam kan WTP bangunan an tenaga lya tenaga tkan keseP.

$\tan$ berpekesediaan asi peneli$k$ ke hutan 'etani beritan, akan hutan jika us petani, lokasi ti- 
dak berpengaruh nyata terhadap tingkat kesediaan petani membayar WTP untuk perbaikan lingkungan. Petani lokal maupun petani pendatang, petani tua maupun muda, dan petani di Sumberjaya maupun Sekincau tidak berbeda dalam membayar WTP. Kemiringan lahan tidak berpengaruh nyata terhadap besar WTP petani di kawasan hutan maupun luar kawasan hutan. Kemiringan lahan tidak berpengaruh nyata karena kemiringan lahan di hutan maupun luar hutan termasuk dalam kelas kemiringan lahan yang hampir sama.

Peningkatan besar kesediaan petani kopi membayar (WTP) untuk perbaikan lingkungan perlu terus dilakukan dengan jalan meningkatkan pengetahuan petani tentang konservasi tanah dan sistem naungan serta pengetahuan petani tentang manfaat hutan. Di samping itu petani diberi kemudahan untuk mendapatkan bibit-bibit tanaman cocok secara teknis dan ekologis, serta mempunyai nilai ekonomi.

Kesediaan membayar petani kopi untuk perbaikan lingkungan merupakan salah satu usaha investasi bagi konservasi sumberdaya hutan dan lingkungan untuk menghambat atau bahkan mencegah kerusakan hutan dan lingkungan akibat alih fungsi lahan hutan menjadi usahatani kopi dan bahkan diharapkan dapat mengembalikan fungsi hutan pada lahan yang ditanami kopi. Peningkatan besar kesediaan petani kopi membayar (WTP) untuk perbaikan lingkungan perlu terus dilakukan

\section{SIMPULAN}

Dalam rangka menekan kerusakan lingkungan dan memenuhi persyaratan sertifikasi kopi, petani kopi di kawasan hutan bersedia membayar (WTP) Rp484.590,00/tahun dan petani di luar kawasan hutan Rp405.036,00/tahun untuk perbaikan konservasi tanah, menambah tanaman naungan, membayar pajak lingkungan, dan kegiatan reboisasi. Di samping bermanfaat secara ekologis, kesediaan petani membayar WTP dapat bermanfaat secara ekonomi yaitu dapat meningkatkan produktivitas lahan dan pendapatan petani. Faktor-faktor yang dapat meningkatkan kesediaan membayar (WTP) adalah luas lahan usahatani, produktivitas lahan, pendapat- an rumah tangga, tingkat pendidikan, jumlah tenaga kerja keluarga, dan pengetahuan petani tentang manfaat hutan, sedangkan jarak rumah petani ke hutan berpengaruh negatif terhadap kesediaan membayar WTP.

Peningkatan besar kesediaan petani kopi membayar (WTP) untuk perbaikan lingkungan perlu terus dilakukan dengan jalan meningkatkan pengetahuan petani tentang konservasi tanah dan sistem naungan serta pengetahuan petani tentang manfaat hutan. Di samping itu petani diberi kemudahan untuk mendapatkan bibit-bibit tanaman cocok secara teknis dan ekologis, serta mempunyai nilai ekonomi. Dengan meningkatnya besar kesediaan petani kopi membayar (WTP) untuk perbaikan lingkungan dapat mengurangi kerusakan hutan dan lingkungan akibat alih fungsi lahan hutan menjadi usahatani kopi dan bahkan diharapkan dapat mengembalikan fungsi hutan pada lahan yang ditanami kopi.

\section{DAFTAR PUSTAKA}

Badan Pusat Statistik. 2008. Lampung Barat Dalam Angka. BPS: Lampung Barat.

Besanko, D. and Braeutigam Ronald R. 2002. Microeconomic. An Integrated Approach. New Jersey: John Wiley and Sons, Inc.

Bishop, R. C., and T. A. Heberlein. 1979. Measuring Values of Extra Market Goods: Are Indirect Measures Biased? American Journal of Agricultural Economics, 61:926--930.

Blackman, A.; B. Avalos-Sartoria \& J. Chow. 2007. Shade Coffee and Tree Cover Loss: Lessons from El Savador. Environment, 49: 22-32.

Borooah, V.K., 2002. Logit and Probit, Ordered and Multinomial Model. London: Sage Publications, Inc. Thousand oaks.

Fauzi, A. 2004. Ekonomi Sumber Daya Alam dan Lingkungan: Teori dan Aplikasi. Jakarta: Gramedia Pustaka Utama.

Greene, W.H. 2002. Econometric Analysis. Second Edition. New York: Macmillan Publishing Company. 
Hernandez-Martinez, G.; R.H. Manson and A.C. Hernandez. 2009. Quantitative Classification of Coffee Agroecosystems Spanning A Range of Production Intensities in Central Veracruz, Mexico. Agriculture, Ecosystems and Environment, 134: 89-98.

Irham. 2005. Menghitung Nilai Ekonomi Lingkungan (Aplikasi Model Hedonik pada Studi Kasus di Jepang. Jurusan Sosial Ekonomi pertanian Fakultas Pertanian UGM.

Kine, A. 2009. Sustainable Coffee Certifications: A Comparison Matrix. SCAA Sustainable Committee. http: www.scaa.org.

Mas, A.H. and T. V. Dietsch. 2003. An Index of Management Intensity for Coffee Agroecosystems to Evaluate Butterfly Species Richness. Ecological Applications, 13: 14911501.

Murniwati, T., R.T.M. Sutamihardja, dan E.I.K. Putri. 2006. Analisis Willingness to Pay Pengelolaan Sampah Pasar Tradisional Kota Bogor. Forum Pascasarjana Vol. 29 No.4 Oktober 2006: 277-287

Pasaribu, L. 2007. Potensi Keanekaragaman Hayati, Status dan Sejarahnya TNBBS Sebagai Situs Warisan Dunia (Tantangan dan Tanggungjawab). Disampaikan pada acara Multistakeholder Workshop tentang Kopi dan Konservasi di dalam dan sekitar TNBBS. Bandar Lampung, 13-14 Maret.

RDV-The World Bank. 2002. Toward More Sustainable Coffee. Agriculture Technology Notes 30: 1-4.

Pearce, D.W., R.K. Turner and I. Bateman. 1994. Economics of Natural Resources and the Environment. New York: Harvester Wheatsheaf.

Pender, J., Suyanto, J. Kerr. 2008. Impacts of the Hutan Kemasyarakatan Social Forestry Program in the Sumberjaya Watershed, West Lampung District of Sumatra, Indonesia. International Food Policy Research Institute. Washington, DC. www.ifpri.org.

Prasmatiwi, F.E., Irham, A. Suryantini, dan Jamhari. 2010. Analisis Keberlanjutan
Usahatani Kopi di Kawasan Hutan Kabupaten Lampung Barat dengan Pendekatan Nilai Ekonomi Lingkungan. Pelita Perkebunan 26(1):65-80

Prasmatiwi, F.E., Irham, A. Suryantini, dan Jamhari. 2010. Faktor-faktor Penentu Adopsi Sistem Naungan dan Pengaruhnya terhadap Produktivitas dan Pendapatan Usahatani Kopi di Kabupaten Lampung Barat. Agriekstensia 9 (2):160 - 172.

Suparmoko. 2006. Ekonomi Sumberdaya Alam dan Lingkungan. Suatu pendekatan Teoritis. Edisi 3. Yogyakarta: BPFE.

Syam, T.; H. Nisdale; A.K. Salam; M. Utomo; A.K. Mahi; J. Lumbanraja; S.G. Nugroho \& M. Kimura. 1997. Land Use and Cover changes in a hilly area of South Sumatra, Indonesia (from 1970 to 1990). Soil Science and Plant Nutrition, 43, 587-599.

Van Noordwijk, M.; S. Rahayu; K. Hairiah; Y. C. Wulan; A. Farida \& B. Verbist . 2002. Carbon Stock Assessment for a Forest-to-Coffee Conversion Landscape in Sumberjaya (Lampung, Indonesia): from Allometric Equations to Land Use Change Analysis. Science in China, 45:75-86.

Verbist B; A. Eka Dinata \& S. Budidarsono. 2005. Factors Driving Land Use Change: Effects on Watershed Functions in a Coffee Agroforestry System in Lampung, Sumatra. Agricultural System, 85:254-270.

Widianto, D. Suprayogo, H. Noveras, R.H. Widodo, P. Purnomosidhi, dan M. van Noordwijk. 2004. Alih Guna Lahan Hutan Menjadi Lahan Pertanian: Apakah Fungsi Hidrologis Hutan Dapat Digantikan Sistem Kopi Monokultur? Agrivita. 26(1): 47-52.

WWF-Indonesia. 2005. Gone in an Instant: Illegal Coffe Growing and Habitat Destruction Bukit Barisan Selatan National Park Sumatra Indonesia. AREAS (Asian Rhino and Elephant Action Strategy) Bukit Barisan Selatan Programme. 